\title{
The relative frequency of primary immunodeficiency diseases in pediatric patients with recurrent sinusitis and otitis media
}

\author{
Farhad Abolnezhadian ${ }^{1}$, Nader Saki $^{2}$, Soheila Nikakhlagh ${ }^{2}$, Elham Safavi ${ }^{1}$, Shideh Asar ${ }^{1}$
}

\begin{abstract}
Background \& Purpose: Recurrent and chronic infections of the ear, throat and nose are one of the most important health problems worldwide, and they clearly affect the quality of life in adults and children. In spite of proper diagnosis and proper treatment, groups of these patients do not respond to routine treatment and are still being symptomatic and have chronic complications in these patients. Various studies have shown that the immune system is defective in some patients with frequent and chronic infections of the ear, throat and nose. Therefore, the present study was conducted to evaluate the relative frequency of primary immunodeficiency diseases in children with sinusitis and recurrent middle ear infections.

Methods \& Materials: This study evaluated underlying immune defects in patients with otitis media or recurrent sinusitis. Serum levels of IgA, IgG and IgM were evaluated by nephlometric test. In addition, a complete count of blood cells was also evaluated. The rate of humoral response to diphtheria and tetanus was also assessed. NBT was used to evaluate the immune system.

Results: Out of 62 patients, 12 patients (19\%) had defects in at least one antibody class. Five patients with IgA deficiency (which 2 of them have also showed IgG concurrent deficiency) were seen. Also, 4 patients had IgG deficiency and 3 patients showed IgM deficiency. None of the patients had abnormal cell count. NBT response was also normal in all patients.

Conclusion: In general, the findings of the present study in line with previous studies showed that a large proportion of children with recurrent otitis media and sinusitis have abnormal immunologic function. Therefore, it is recommended that the evaluation of immune deficiency be considered in these patients.
\end{abstract}

Keywords: otitis media, sinusitis, children, serum immunoglobulin level

\section{INTRODUCTION}

Recurrent sinusitis and otitis media are one of the most common infectious diseases in the world that clearly affect the patient's quality of life and disrupts the patient's performance $(1,31)$. According to the definition, recurrent otitis media and sinusitis, are presentation of four separate episodes of acute otitis media or sinusitis in 12 months $(2,3)$. Diseases and risk factors can be the cause of this frequent infection, which the primary immunodeficiency is most important (4). Other causes include allergic rhinitis, asthma, polyps (5), cystic fibrosis (6), sinobronchial syndrome, Wegener's granulomatosis (2) ciliary impairment $(7,8)$.

Primary Antibody deficiency (PAD) is the most common type of primary immunodeficiency which accounting for more than half of the immune deficiencies (9-12). The spectrum of this defect of antibodies is very wide, range from an absolute deficiency of a specific antibody to a complete absence of B cells (13). The main presentation of this immunodeficiency are frequent and chronic infections, which are mainly bacterial, the most common of which are Haemophilus influenzae, Staphylococcus aureus, Streptococcus pneumonia and Pseudomonas (14-16). Occasionally, ear, throat and nose infections are the first manifestation of primary immunodeficiency (17), which unfortunately in some cases are not diagnosed due to lack of knowledge of doctors and lead to irréparable complications, even cause death in some cases (18). Timely diagnosis and proper treatment seems to reduce these patients' mortality and also increase the

\footnotetext{
Assistant professor of Pediatric Department, Abuzar Children's Hospital, Ahvaz Jundishapur University of Medical Sciences, Ahvaz, Iran.

2 Associated Professor of otolaryngology Department, Hearing research center, Ahvaz Jundishapur University of Medical Sciences, Ahvaz, Iran.
}

Received: 5 Aug 2018, Accepted: 13 Nov 2018

\section{Correspondence: Shideh Asar \\ Associated professor. Pediatric Department, Abuzar Children's Hospital, Ahvaz Jundishapur University of Medical Sciences, Ahvaz, Iran}

E-mail:assarsh@yahoo.com

(C) 2019 by the authors; licensee Modestum Ltd., UK. This article is an open access article distributed under the terms and conditions of the Creative Commons Attribution License (http://creativecommons.org/licenses/by/4.0/). 
Table 1: Serum levels of antibodies in the studied patients

\begin{tabular}{|c|c|c|c|c|c|}
\hline Variables & Mean & Median & S.d & Min & Max \\
\hline Age & 5.72 & 5 & 3.84 & 1 & 17 \\
\hline $\lg A$ & 120.93 & 126 & 64.23 & 6.1 & 291 \\
\hline $\lg M$ & 104.95 & 104 & 46.23 & 3 & 217 \\
\hline $\lg G$ & 1096.52 & 1020 & 446.16 & 169 & 2581 \\
\hline NBT & 95.51 & 96 & 3.6 & 87 & 100 \\
\hline Anti tetanus Toxoid & 1.7 & 1.4 & 1.3 & 0.05 & 6.2 \\
\hline Anti Diphtheria & 0.77 & 0.5 & 0.72 & 0.05 & 2.73 \\
\hline
\end{tabular}

quality of life of patients (19-22). In some studies, it has been shown that $70-91 \%$ of immunocompromised patients develop ear, throat and nose infections $(14,23)$.

Reviewing of the previous studies have risen the question, whether the routine request for testing of immune system in all patients with recurrent episode infections of otitis media and sinus, without any knowledge of the relative frequency of these defects in this group of patients, had a scientific justification?, is it possible to generalize the results of these studies to Ahvaz, and in the end do the tests are cost-beneficial in our patients. We believe that answering these questions will be an introduction to the formulation of regional and local protocols and guidelines in our centers. The aim of this study was to determine the relative frequency of immune deficiency in children with recurrent sinusitis and otitis media referring to Golestan \& Abozar Hospitals, Ahvaz in Southwest of Iran.

\section{MATERIALS AND METHODS}

\section{Study Design}

In this study, 100 patients under 18 years old with recurrent otitis media recurrent sinusitis whose disease was confirmed by otolaryngologist according to the American guideline, using fully clinical and paraclinical findings, were enrolled. Following the identification of patients, the checklist was designed to collect demographic information and medical history and otolaryngology infection. Patients with allergic rhinitis, asthma, cystic fibrosis, sinobronchial syndrome, Wegener's granulomatosis, Ciliary impairment were excluded. Written consent were given to all of the patients for participation in the study and performing tests. This study was approved by the Ethics Committee of Ahvaz Jundishapur University of Medical Sciences.

\section{Measurements}

Blood sample were collected after obtaining the history and physical examination. The samples were evaluated for IgG, IgA, IgM, Anti Tetanus Ab, Anti Diphtheria Ab, NBT, using nephlometric method. Selective IgA deficiency diagnosed with a decrease in serum IgA levels Below $7 \mathrm{mg} / \mathrm{dL}$ and the normal level of $\lg \mathrm{G}$ and $\lg \mathrm{M}$ immunoglobulins and the rejection of other causes of primary immunodeficiency. Common defective immune deficiency (CVID) diagnosis based on hypogammaglobulinemia and absence of other known causes of genetic hypogammaglobulinemia.

\section{Statistical Analysis}

To describe the data, the mean and standard deviation were used in quantitative variables and the frequency were used to express the qualitative variables. The normal distribution of data was assessed by Kolmogorov Smirnov test . The Chi-square tests, t-test (or Mann-Whitney test) and Pearson correlation coefficient (or Spearman) were used to analysis the data. All statistical analysis were performed using SPSS version 20.

\section{RESULTS}

In this study, 100 patients were evaluated, and 62 patients met the inclusion criteria. The mean age of patients was 5.7 (range 1 to 17 ) years. In addition, 41 (66.1\%) patients were boys and 21 were girls. The serum levels of examined antibody are shown in Table 1.

Overall, 14 patients had abnormalities in the humoral immune system. Of these, 12 patients showed selective antibody deficiency and 2 other patients had hyper IgM syndrome. In general, the most common disorder were $\lg \mathrm{A}$, $\lg$ and $\lg \mathrm{M}$ deficiencies, respectively. It should be noted that 2 of the patients showed a deficiency of both $\lg G$ and $\lg A$ immunoglobulin (Table 2). The conclusive diagnosis in the patients were achieved after complementary analysis. According that the selective IgA deficiency were the most common disorder with frequency of $5 \%$. The frequency of Burton disease, Hypogamaglubulonemia, transient hypoglubulonemia and hypo IgM were similar (2\%) (Table 3). 
Table 2: Frequency of the antibody disorders

\begin{tabular}{lll}
\hline Disorders & Frequency & Percent \\
\hline $\lg$ deficiency & 3 & 5 \\
\hline $\lg$ deficiency & 4 & 7 \\
\hline IgA deficiency & 5 & 8 \\
\hline Hyper IgM & 2 & 3 \\
\hline $\operatorname{lgG}$ and IgA deficiency & 2 & 3 \\
\hline Anti diphtheria Ab deficiency & 4 & 7 \\
\hline Anti diphtheria Ab and IgG and IgA deficiency & 1 & 2 \\
\hline IgG and anti diphtheria Ab deficiency & 1 & 2 \\
\hline Hyper IgM and Anti diphtheria Ab deficiency & 1 & 2 \\
\hline
\end{tabular}

Table 3: Frequency of immunogenic disorders

\begin{tabular}{lcc}
\hline Disorders & Frequency & Percent \% \\
\hline Buroton & 1 & 2 \\
\hline Selective IgA deficiency & 3 & 5 \\
\hline Hypogamaglubulonemin & 1 & 2 \\
\hline Transient Hypogamaglubulonemin & 1 & 2 \\
\hline Hyper IgM & 1 & 2 \\
\hline
\end{tabular}

\section{DISCUSSION}

The recurrent and chronic infections of the ear, throat and nose are one of the most important health problems worldwide, and they clearly affect the quality of life in adults and children $(24,25,31)$. In spite of proper diagnosis and proper treatment, groups of these patients do not respond to routine treatment and are still being symptomatic and have chronic complications. Several studies have examined the immune system in patients with recurrent and chronic infections of the ear, throat and nose $(26,27)$. In these studies, deficiencies in immunoglobulins and lack of response to polysaccharide and protein antigens have been detected in some of patients. In addition, in some patients with antibody deficiency, despite the long-term treatment of drugs (with antibiotics and topical steroids) or treatment with immunoglobulins, the incidence of chronic rhinosinusitis can continue. Even painless polyps can be created.

In the present study selective deficiency of $\operatorname{lgG}, \operatorname{IgM}$ and $\lg A$ were present in 12 patients out of 62 patients (19\%). The most common anomalies were IgA deficiency (8\%), IgG deficiency (6.6\%), and IgM deficiency (4.8\%). In line with these findings, a study by Karimi and colleagues on 101 children with recurrent ENT infections assessed the humoral immune response of patients and showed that $20.8 \%$ of them had humoral immunodeficiency. In this study, contrary to the present study, IgG subgroups were also evaluated (27). In addition, in a study by Finochi et al., On 67 children with recurrent infections, it was shown that $55 \%$ of patients had low levels of antibodies and the most common are IgA deficiency. The reason for the discrepancy between these findings and the present study is due to the difference in the population studied (26). On the other hand, May and colleagues in a study of 245 patients with recurrent-resistance rhinosinusitis showed 22 patients (11\%) had immunoglobulin deficiencies (28).

In the present study, 2 patients had $\lg A$ and $\lg G$ deficiencies that did not provide optimal response to received vaccines. It has been shown that patients with IgA deficiency usually show a deficiency of immunoglobulin $\mathrm{G}$ level. Similarly, Ozkan and colleagues in a study of 255 children with recurrent sinus and respiratory tract infections showed that the prevalence of $\lg \mathrm{G} / \operatorname{lgA}$ deficiency in these patients was approximately $1.4 \%$. In addition, in line with our results they also reported the overall antibody deficiency is $19.1 \%$ (29).

It was also shown that two patients with $\operatorname{lgM}$ levels higher than normal. These patients showed isolated increased IgM and did not show any other antibody deficiency. In patients with hyper-IgM syndrome, patients should exhibit a decreased level of other immunoglobulins (30). Therefore, the increase in $\lg \mathrm{M}$ in these two patients can be due to a recent immunogenic response or measurement error. In any case, further evaluations are needed to determine the conclusive cause.

In general, the findings of the present study in completing previous studies showed that a large proportion of children with recurrent otitis media and sinusitis have antibody deficiency of different classes. Therefore, it is recommended that these patients evaluate for the humoral immune response. The lack of evaluation of antibody subclasses such as the lgG sub class was subject to the limitations of the present study. 


\section{ACKNOWLEDGEMENTS}

This article was the result of the dissertation thesis on U-96065 issued by the Committee on Ethics of the University (approved number IR.AJUMS.REC.1396.330). This study was funded by the Vice-Chancellor for Research at the University. We thank all our colleagues in Golestan Hospital, Ahvaz, Iran.

\section{REFERENCES}

1. Amirzargar A, Feghhi S, Nicknam MH, Saki N. Immunological aspects of secretory otitis media in Iranian children, immunoglobulin and complement concentration in serum and glue. Iran J Allergy Asthma Immunol. 2003 Mar;2(1):25-30. PMid:17301353

2. Benninger MS, Ferguson BJ, Hadley JA, et al. Adult chronic rhinosinusitis: definitions, diagnosis, epidemiology, and pathophysiology. Otolaryngol Head Neck Surg. 2003;129:1-32. https://doi.org/10.1016/S01945998(03)01397-4

3. Pichichero ME, Casey JR. Otitis media. Expert Opin Pharmacother 2002;3:1073-90. https://doi.org/10.1517/14656566.3.8.1073 PMid:12150687

4. Buckley RH. Pulmonary complications of primary immunodeficiencies. Paediatr Respir Rev.2004;5:225-33. https://doi.org/10.1016/S1526-0542(04)90043-7

5. Saki N, Nikakhlagh S, Ahmadi KH. Comparison of PCR Assay and Culture for Detecting Bacteria in Middle Ear Fluid of Children with Otitis Media with Effusion. Int Advance Otolryngol. 2009;5(1):31.

6. Ramsey B, Richardson MA. Impact of sinusitis in cystic fibrosis. J Allergy Clin Immunol.1992;90:547-52. https://doi.org/10.1016/0091-6749(92)90183-3

7. Rayner $\mathrm{CF}$, Rutman $\mathrm{A}$, Dewar $\mathrm{A}$, et al. Ciliary disorientation in patients with chronic upper respiratory tract inflammation. Am J Respir Crit Care Med. 1995;151:800-4. https://doi.org/10.1164/ajrccm/151.3_Pt_1.800 PMid:7881674

8. Umetsu DT, Ambrosino DM, Quinti I, et al. Recurrent sinopulmonary infection and impaired antibody response to bacterial capsular polysaccharide antigen in children with selective IgG-subclass deficiency. N Engl J Med 1985;313:1247-51. https://doi.org/10.1056/NEJM198511143132002 PMid:3877240

9. Luzi G, Businco L, Aiuti F. Primary immunodeficiency syndromes in Italy: a report of the national register in children and adults. J Clin Immunol. 1983;3:316-20. https://doi.org/10.1007/BF00915792 PMid:6655036

10. Matamoros Flori N, Mila Llambi J, Espanol Boren T, et al. Primary immunodeficiency syndrome in Spain: first report of the National Registry in Children and Adults. J Clin Immunol. 1997;17:333-9. https://doi.org/10.1023/A:1027382916924 PMid:9258772

11. Aghamohammadi A, Moein M, Farhoudi A, et al. Primary immunodeficiency in Iran: first report of the National Registry of PID in Children and Adults. J Clin Immunol. 2002;22:375-80. https://doi.org/10.1023/A:1020660416865 PMid:12462337

12. Leiva LE, Zelazco $M$, Oleastro $M$, et al. Primary immunodeficiency diseases in Latin America: the second report of the LAGID registry. J Clin Immunol. 2007;27:101-8. https://doi.org/10.1007/s10875-006-9052-0 PMid:17191150

13. Bonilla FA, Bernstein IL, Khan DA, et al. Practice parameter for the diagnosis and management of primary immunodeficiency. Ann Allergy Asthma Immunol. 2005;94:1-63. https://doi.org/10.1016/S1081-1206(10)611428

14. Cunningham-Rundles $C$, Bodian $C$. Common variable immunodeficiency: clinical and immunological features of 248 patients. Clin Immunol. 1999;92:34-48. https://doi.org/10.1006/clim.1999.4725 PMid:10413651

15. Hermaszewski RA, Webster AD. Primary hypogammaglobulinaemia: a survey of clinical manifestations and complications. Q J Med. 1993;86:31-42. PMid:8438047

16. Aghamohammadi $A$, Farhoudi $A$, Moin $M$, et al. Clinical and immunological features of 65 Iranian patients with common variable immunodeficiency. Clin Diagn Lab Immunol. 2005;12:825-832. https://doi.org/10.1128/CDLI.12.7.825-832.2005

17. Galicia G, Betancourt MA, Canales LE, et al. Ear, nose, and throat manifestations in patients with primary immunodeficiencies. Rev Alerg Mex. 1999;46:108-19. PMid:10488654

18. Seymour B, Miles J, Haeney M. Primary antibody deficiency and diagnostic delay. J Clin Pathol. 2005;58:546-7. https://doi.org/10.1136/jcp.2004.016204 PMid:15858130 PMCid:PMC1770645 
19. Tahkokallio O, Seppala IJ, Sarvas $\mathrm{H}$, et al. Concentrations of serum immunoglobulins and antibodies to pneumococcal capsular polysaccharides in patients with recurrent or chronic sinusitis. Ann Otol Rhinol Laryngol 2001;110(7 Pt 1):675-81. https://doi.org/10.1177/000348940111000714 PMid:11465828

20. Shapiro GG, Virant FS, Furukawa $\mathrm{CT}$, et al. Immunologic defects in patients with refractory sinusitis. Pediatrics 1991;87:311-6. PMid:2000270

21. Finocchi A, Angelini $F$, Chini $L$, et al. Evaluation of the relevance of humoral immunodeficiencies in a pediatric population affected by recurrent infections. Pediatr Allergy Immunol 2002;13:443-7. https://doi.org/10.1034/j.1399-3038.2002.02088.x PMid:12485321

22. Sethi DS. Immunologic defects in patients with chronic recurrent sinusitis: diagnosis and management.Otolaryngol Head Neck Surg. 1995 Feb;112(2):242-7. https://doi.org/10.1016/S01945998(95)70244-X

23. Plebani A, Soresina A, Rondelli $R$, et al. Clinical, immunological, and molecular analysis in a large cohort of patients with X-linked agammaglobulinemia: an Italian Multicenter Study. Clinical Immunology. 2002;104:221230. https://doi.org/10.1006/clim.2002.5241 PMid:12217331

24. Gliklich RE, Metson R. The health impact of chronic sinusitis in patients seeking otolaryngologic care. Otolaryngol Head Neck Surg. 1995;113(1):104-9. https://doi.org/10.1016/S0194-5998(95)70152-4

25. Wiertsema SP, Veenhoven RH, Sanders EA, et al. Immunologic screening of children with recurrent otitis media. Curr Allergy Asthma Rep. 2005;5(4):302-7. https://doi.org/10.1007/s11882-005-0070-4 PMid:15967072

26. Finocchi A, Angelini F, Chini L, et al. Evaluation of the relevance of humoral immunedeficiencies in a pediatric population affected by recurrent infections. Pediatr Allergy Immunol. 2002;13(6):443-7. https://doi.org/10.1034/j.1399-3038.2002.02088.x PMid:12485321

27. Karimi A, Isaiyan A, Aghamohammadi A, Moin M, Zandiyeh F, Dini AT, Abdollahzade S, Tahayi AH, Sazgar AA. Immunological evaluation of children with recurrent ear, nose, and throat (ENT) infections. Iranian Journal of Pediatrics. 2007;17(Suppl 1):5-13.

28. May A, Zielen S, Von Ilberg C, Weber A. Immunoglobulin deficiency and determination of pneumococcal antibody titers in patients with therapy-refractory recurrent rhinosinusitis. European archives of oto-rhinolaryngology. 1999 Oct 1;256(9):445-9. https://doi.org/10.1007/s004050050186 PMid:10552223

29. Ozkan H, Atlihan F, Genel F, Targan S, Gunvar T. IgA and/or IgG subclass deficiency in children with recurrent respiratory infections and its relationship with chronic pulmonary damage. J Investig Allergol Clin Immunol. 2005 Jan 1;15(1):69-74. PMid:15864886

30. de la Morena MT. Clinical phenotypes of hyper-IgM syndromes. The Journal of Allergy and Clinical Immunology: In Practice. 2016 Nov 1;4(6):1023-36. https://doi.org/10.1016/j.jaip.2016.09.013 PMid:27836054

31. Saki N, Rahim F, Nikakhlagh S, M Sarafraz, E Jafarzadeh. Quality of life in children with recurrent acute otitis media in southwestern of Iran. Indian J Otolaryngol Head Neck Surg 2014; 66:267-70. https://doi.org/10.1007/s12070-012-0479-8 PMid:24533396 PMCid:PMC3918277

$\diamond \diamond \diamond \diamond \diamond \diamond \diamond$

http://www.ejgm.co.uk 